\title{
HSOA Journal of Neonatology and Clinical Pediatrics
}

\section{Characteristics of General Movement in Infants Prenatally Exposed to Methamphetamine}

\author{
Angela O'Connor ${ }^{1 *}$ (D), Emma Harris ${ }^{2}$, Natasha Amery ${ }^{3}$, Carly \\ Seeber $^{4}$, Dale Hamilton ${ }^{5}$, Colleen Fisher ${ }^{6}$ and Mark Sachmann ${ }^{7}$
}

${ }^{1}$ Clinical Midwifery Consultant University of Western Australia, King Edward Memorial Hospital University of Western Australia, Australia

${ }^{2}$ Consultant Neonatologist KEMH, King Edward Memorial Hospital, Australia

${ }^{3}$ Physiotherapist, Neonatology, King Edward Memorial Hospital, Australia

${ }^{4}$ Senior Registrar Neonatology KEMH, King Edward Memorial Hospital, Australia

${ }^{5}$ Consultant Obstetrician, King Edward Memorial Hospital, Australia

${ }^{6}$ University of Western Australia, Professor Head of School of Population \& Global Health, Australia

${ }^{7}$ University of Western Australia, School of Allied Health. UWA, Australia

\begin{abstract}
General Movements (GMs) assessment is an original approach to predict early brain dysfunction following prenatal exposure to Methamphetamine (MA) in a group of high -risk infants attending the Women and Newborn Drug and Alcohol Service. Prechtl's General Movement assessment has demonstrated an excellent marker to predict Cerebral Palsy (CP).
\end{abstract}

Aim: To evaluate whether a detailed assessment of General Movements in high-risk infants is predictive of neurological impairments in infants exposed to methamphetamine in pregnancy.

Method: A mixed-methods prospective study of 112 high-risk infants, using video recordings at birth and at 4 months post-birth. A detailed history of neonates following birth including birth details, mode of delivery, maternal drug use and socio-economic status, infants

*Corresponding author: Angela O'Connor, Clinical Midwifery Consultan University of Western Australia, King Edward Memorial Hospital University of Western Australia, Australia, Tel: +61 0408924647 / +61 864581582; E-mail: solushealing@bigpond.com / angela.o'connor@health.wa.gov.au

Citation: O'Connor A, Harris E, Amery N, Seeber C, Hamilton D, et al. (2020) Characteristics of General Movement in Infants Prenatally Exposed to Methamphetamine. J Neonatol Clin Pediatr 7: 057

Received: September 20, 2020; Accepted: September 28, 2020; Published: October 05, 2020

Copyright: (c) 2020 O'Connor A, et al. This is an open-access article distributed under the terms of the Creative Commons Attribution License, which permits unrestricted use, distribution, and reproduction in any medium, provided the origina author and source are credited. condition at birth, growth parameters, Apgar scores, infection and any admissions to Special Care Nursery were recorded. The videos were assessed by two separate professionals trained in Prechtl's method of assessing General Movements. A Griffith developmental assessment was undertaken at 12 months and the results compared to the optimality scores using a Pearson correlation.

Results: Of the 100 infants assessed in the newborn period, of these, $n=24(21.4 \%)$ had normal assessment (low risk of Cerebral palsy), $\mathrm{n}=50(44.6 \%)$ had poor repertoire and $2(1.8 \%)$ had Cramped-Synchronized, Hypokinetic $n=23(20.5 \%)$. At 4 months 75 infants were assessed as normal fidgety movements and 2 infants had absent fidgety movements. One infant developed Cerebral Palsy and six infants were referred for Developmental assessment at 12 months. There was no significant correlation between motor optimality scores and Griffith's scores at 12 months.

Conclusion: This is the first study to our knowledge to report on general movements in this population. We found a high rate of poor repertoire in the first week of life however no increased rate of Cerebral Palsy. Motor optimality scores did not correlate with developmental outcomes at 12 months.

Keywords: Alcohol service; Cerebral palsy; General movements assessment; Methamphetamine exposure; Optimality scores; Women and newborn drug

\section{Introduction}

Methamphetamine use (MA) in pregnancy has been shown to affect the growth and development of the infant's and results in long term developmental issues [1-4]. Data is scarce in regards to the impact of prenatal exposure of MA use has on the development of the infant. This is largely due to the difficulty in separating the effect of the drug/s from other adverse social circumstances including poverty [5], mental health issues [6,7], family and domestic violence $[8,9]$ and poor nutrition $[10,11]$. It is generally agreed that these infants may certainly be at risk of developmental impairment and that they warrant formal follow-up [12-15]. This research aims to gather data on the health of these infants at birth, and evaluate whether a detailed assessment of GMs in high- risk infants is predictive of neurological impairments in infants exposed to MA in pregnancy.

Prechtl's qualitative assessment of General Movements (GMs) has been widely used as a tool for early identification of infants with neurodevelopmental disabilities [16,17]. To the best of our knowledge, this method has not been reported in MA exposed infants before but has been shown to be useful in describing the abnormalities seen after exposure to Selective Serotonin Reuptake Inhibitor (SSRI) medications in utero [18]. Other Neonatal Examination Scoring systems (NNNS) have been documented in the Infant Development and Lifestyle Study (IDEAL) [4], but this tool is not generally used in Australasia and was therefore not chosen for our research $[16,17]$.

The assessment of General Movements is a method that takes the complexity of the infant's nervous system fully into consideration at the time of assessment $[19,20]$. General Movement Assessment 
Citation: O’Connor A, Harris E, Amery N, Seeber C, Hamilton D, et al. (2020) Characteristics of General Movement in Infants Prenatally Exposed to Methamphetamine. J Neonatol Clin Pediatr 7: 057.

(GMA) is based on visual Gestalt perception [21]. General movements are considered to be normal if the sequence, amplitude, speed, and intensity are variable [16,22]. Abnormal general movements are characterized by a lack of variability, especially in the movement sequence and Hypokinetic' indicates that general movements cannot be observed during the whole recording, but isolated (usually upper) limb movements are present. In this case, a detailed assessment cannot be carried out $[21,23]$.

The young human nervous system generates endogenously $[24,25]$. In the infant, a large variety of specific movement patterns, such as startles, GMs, isolated limb movements, stretches, yawning, and breathing movements emerge at 9 to 12 weeks' postmenstrual age $[17,26]$. These endogenously generated movement patterns continue after birth and continue for the first six months post-birth (Appendix 1).

GM's assessments in this high-risk infant study will add to the current body of evidence regarding the impact of prenatal MA use and polysubstance use has on the infant's development [4,27]. Prechtl's General Movements assessments is a method of evaluating the movements of infants has been shown to be highly sensitive and specific in predicting future neurodevelopmental disability, particularly cerebral palsy [16,23]. Einspieler et al presented a motor optimality score based both on standard GMA and on the assessment of other postures and movements than FM [28]. They suggests that a low motor optimality score is associated with limited functional mobility and activity. The aim of this study is to compare Prechtl's GM's assessment as a non-invasive qualitative way of evaluating the infant's nervous system [21,29] with infant developmental outcomes for up to 12 months.

\section{Methods}

\section{Participants}

This mixed-methods prospective study was performed as a singleblind study in term and preterm high-risk infants at the Women and Newborn Drug and Alcohol Service (WANDAS) in Perth Western Australia. Using a qualitative assessment of spontaneous General Movements video (GMs) in the infant's at risk is a valid and reliable tool for evaluation.

Recruitment took place between July 2015 and December 2017. Women who had been accepted for antenatal care with the service and identified MA use as being their primary drug of choice were approached to participate. A standardised drug and alcohol assessment tool [30] was administered to document current and previous use of alcohol and other drugs during each trimester of pregnancy. Polysubstance use was assessed and included. Written informed consent was provided by mothers or Child Protection and Family Support (CPFS) if the infant was in care. Term and preterm high- risk infants exposed to Ma during pregnancy were included. Two video recordings were undertaken one within the first week and the second at 4 months corrected age if preterm infant. A Griffith Developmental assessment was undertaken at 12 months using the Griffith Mental Developmental Assessment. The exclusion criteria for the study were; infants with congenital malformations, genetic and metabolic diseases and ongoing ventilation therapy.

\section{Ethics}

Ethics approval was granted by Western Australia's Women and Newborn Health Service Human Research Ethics Committee, University of Western Australia, the Western Australian Aboriginal Health Ethics Committee and by Western Australia's Department for Child Protection and Family Support.

\section{General movement assessment}

GM's assessment was performed in the first -week post-birth (generally around day 3-5) and again at 4 months corrected age. Video recordings were performed according to Prechtl's GMA methodology [24]. A video camera was stabilized on a tripod and the infants were videoed during an active wakeful state while lying supine on a cot and a mattress at 4 months. The infants wore a nappy and were placed under a warmer to ensure comfort and temperature control. The video recording was performed by the hospital's medical illustrations department for consistency and reliability. The video clips used for this analysis lasted 20 minutes and contained at least three GMs. Two assessors evaluated the video's both having trained in GMA assessment. One assessor was blinded to the medical history and also performed a motor optimality score (maximum score 430 [23]. In the case of a disagreement of the general movement type, a consensus was reached between the assessors or a third party would be used. The findings were classified as Normal (N), Poor Repertoire (PR), or Cramped- Synchronised (CS) in the writhing period, and as Normal fidgety (N), Abnormal Fidgety (AF), or absence of Fidgety (F-) movements in the fidgety period. Developmental quotients using the Griffith Developmental Mental assessment at 12 months were compared to motor optimality scores using regression analysis. The infants enrolled in the study were all examined and had a Griffith Developmental assessment, examination and any concerns arising would lead to a referral for ongoing follow up at child developmental services.

\section{Data Analysis}

Descriptive statistics were calculated to describe the study sample as a whole. A phenomenological-hermeneutic analysis was carried out on the data material from the GMs video observations [31]. The interpretation process followed the hermeneutic circle from whole to part and part to whole. Study data were collected and managed using REDCap electronic data capture tools hosted at the University of Western Australia [32]. Maternal MA use was classified into mild, ( $0-2$ points per day) moderate ( 5 points a day) or heavy ( 10 or above points per day, 10 points $=$ to 1 gram of methamphetamine) use during pregnancy. Statistical analyses were performed using SPSS statistical software (version 22.0, IBM SPSS Statistics for Windows, Armonk, NY: IBM Corp). Kruskal Wallis Test was used to correlate the assessment of GMs and the Mann-Whitney $U$ test and Chisquare test was used to compare differences between the observers and between variables of GMS at birth and 4 months. Pearson's correlation was undertaken between optimality scores and Griffiths Mental Developmental scores at 12 months. Throughout the analyses, $\mathrm{p}<0.05$ (two-tailed) was considered to be statistically significant.

\section{Results}

\section{Maternal factors}

The majority of the women used methamphetamine via the intravenous route either daily or binge use which was consistent 
Citation: O’Connor A, Harris E, Amery N, Seeber C, Hamilton D, et al. (2020) Characteristics of General Movement in Infants Prenatally Exposed to Methamphetamine. J Neonatol Clin Pediatr 7: 057.

use over a period of a few days (79.5\%), $n=8917.9 \%(n=20)$ of the mothers reported polysubstance, in that they reported regularly using more than two different drugs, (excluding prescribed medications). The majority of the women $(87.5 \%, \mathrm{n}=98)$ were cigarette smokers. $27 \%(n=30)$ of the women reported drinking alcohol The mean age of the women was 28.9 years and the age ranged from 17 to 41 years old.

$52.7 \%(n=59)$ of the women identified as Aboriginal, $44.6 \%$ $(\mathrm{n}=50)$ of the women identified as being Caucasian and 2.7\% $(\mathrm{n}=$ 3) were of an ethnic background other than Caucasian or Aboriginal. Specifically, these women were Maori, Fijian, and Polynesian. The majority of the women $93.7 \%,(n=105)$ had not completed high school. Only $7.3 \%(n=8)$ of our population were employed. The women reported a high incidence of family and domestic violence $86.6 \%,(n=97), 20$ women were in prison and the remainder resided in the most disadvantaged areas of Perth.

\section{Neonatal outcomes}

A quarter of our infants (24.8\%) were premature born at $<37$ weeks gestation at birth. The mean gestational age was 34 weeks. As noted above 62 were male and 52 infants were female. The median birth weight centile for the infants was $29^{\text {th }}$. Overall $23.8 \%$ of the infants had a birth weight below the $10^{\text {th }}$ centile for gestation. The median head circumference centile was on $34^{\text {th }}$. The most common reason for admission to our Special Care Nursery Unit (SCN) was for respiratory distress (41\%). We analysed the video recordings of 99 infants and compared the influence of neonatal variables on general movements and found no significant difference found between variables (Tables 1 $\&$ 2). One infant was diagnosed with $\mathrm{CP}$ and a hearing deficit.

\begin{tabular}{|c|c|c|c|c|c|}
\hline \multicolumn{7}{|c|}{ General movements assessment at birth } \\
\hline & Frequency & Percent & $\begin{array}{c}\text { Valid } \\
\text { Percent }\end{array}$ & $\begin{array}{c}\text { Cumulative } \\
\text { Percent }\end{array}$ \\
\hline \multirow{4}{*}{ Valid } & Normal & 24 & 21.4 & 21.4 & 55.4 \\
\cline { 2 - 6 } & Poor Repertoire & 50 & 44.6 & 44.6 & 100 \\
\cline { 2 - 6 } & Cramped-Synchronised & 2 & 1.8 & 1.8 & 13.4 \\
\cline { 2 - 6 } & Hypokinetic & 23 & 20.5 & 20.5 & 33.9 \\
\cline { 2 - 6 } & Absent (Did not attend) & 13 & 11.6 & 11.6 & 11.6 \\
\cline { 2 - 6 } & Total & 112 & 100 & 100 & \\
\hline
\end{tabular}

Table 1: General Movement Assessment at Birth and at 4 Months.

\begin{tabular}{|c|c|c|c|c|c|}
\hline \multirow{2}{*}{ Neonatal variables } & \multicolumn{2}{|c|}{$\begin{array}{c}\text { Normal writhing } \\
(\mathbf{n}=\mathbf{2 4})\end{array}$} & \multicolumn{2}{|c|}{$\begin{array}{c}\text { Poor repertoire } \\
\text { (n=52) }\end{array}$} & \multirow{2}{*}{$\boldsymbol{p}$ value } \\
\cline { 2 - 5 } & Mean & SD $^{*}$ & Mean & SD* $^{*}$ & \\
\hline Birth Weight (g) & 2994 & 449 & 3009 & 599 & $\mathbf{0 . 8 8 0}$ \\
\hline Birth Length (cm) & 48.4 & 2.6 & 47.9 & 4.1 & 0.826 \\
\hline Head circumference (cm) & 33.3 & 1.4 & 33.6 & 2.1 & 0.323 \\
\hline Gestational age (weeks) & 38.3 & 1.9 & 37.7 & 1.8 & $\mathbf{0 . 0 4 5}$ \\
\hline Apgar at 1 min & 8 & 1.7 & 7 & 2.3 & 0.228 \\
\hline Apgar at 10 min & 9 & 0.8 & 9 & 0.9 & 0.245 \\
\hline GM Optimality Score & 32 & 4 & 23 & 7 & $\mathbf{0 . 0 0 0}$ \\
\hline Male & 13 & - & 30 & - & \multirow{2}{*}{0.251} \\
\hline Female & 11 & - & 22 & - & \\
\hline
\end{tabular}

Table 2: Influences of neonatal variables on writhing GMs. At Birth. *SD: Standard deviation

\section{General movement outcomes}

Fifty of the video recordings were assessed as poor repertoire (44.6\%), this group with PR had a mean birth weight of 3009 grams, the mean head circumference was $33.6 \mathrm{cms}$ and the mean Apgar score was 7 at 1 minute and 9 at 5 minutes. These infants were sleepy postbirth and were slow to feed [33]. Normal GM was recorded for only (21.4. \%) $n=24$.

The two infants found to have Cramped Synchronised (CS) movements $(1.8 \%)$ had the following history. The women had a history of limited antenatal care, they injected MA and used up to 1 gram per week with some binge pattern. Both had a history of polysubstance use. Both of the women smoked on average 25 cigarettes per day. The infants had a mean birth weight of 2330 grams, head circumference of $33.3 \mathrm{cms}$ (p 0.323) and Apgar scores of 8 and 9 and 6 and 9. Both infants required admission to the Special Care Nursery (SCN) and required Continuous Positive Airway Pressure (CPAP). The infants spent on average two months in SCN and were discharged to maternal care under Child Protection \& Family Support (CPFS) but later were placed into out of home care. At 4 months they had normal fidgety observations and normal Griffiths Mental Developmental assessment at 12 months with General Quotient's (GQ) of 95 and 97. Their Mean Optimality Scores (OS) were low 13 and 20.

At 4 months the 2/77 infants with absent fidgety movements had the following history, infant one was born at 38 weeks and he weighed 3735 grams, HC $36 \mathrm{cms}$, Apgars 9, and 9. The infant had hypokinetic movements at first recording and absent fidgety at 4 months. His OS was 18 and at 12 months developmental assessment his GQ was 58 but no signs of cerebral palsy on examination. He was referred for ongoing developmental follow up. The infant was placed into CPFS care. Maternal history was one of chaotic lifestyle, early pregnancy prison term followed by binge IVDU of MA.

The second infant with absent fidgety movements was a male infant born preterm at 34 weeks; he weighed 2490 grams, $\mathrm{HC}$ of $31 \mathrm{cms}$ and Apgars of 8 and 8 . He required admission to SCN for CPAP. General movement assessment at first recording was PR assessment and absent GMA at four months with an OS of 10. At 12 months he had a normal examination with a GQ was 87 . He was initially allowed home with his mother under CPFS care but was later removed and placed into out of home care due to IVDU and family and domestic violence. Our male infant who was diagnosed with a left hemiplegic cerebral palsy with right-sided schizencephaly and pachygyria on MRI brain was born at 38 weeks following a normal delivery. The infant weighed 2670 grams, Apgars 8 and 8 , HC $35 \mathrm{cms}$. He was admitted to SCN and did not have a writhing age video. At 4 months he had reduced fidgety movements but not absent movements and an OS score of 26. At 16 months he returned for his Griffith's Mental Developmental assessment and had a GQ of 89. He was referred for ongoing developmental assessment. He was discharged home with CPFS support to the care of the mother. Maternal history was one of IVDU of MA daily with polysubstance use of alcohol, and cannabis. The mother was prescribed anti epileptics and was treated with SSRI medication for depression.

We found no statistical difference between groups but we did identify that the infants had a high incidence of PR movements $(44.6 \%)$ at the time of their first recording. The mean Motor Optimality score was 26 was found during the writhing movements. 
Citation: O’Connor A, Harris E, Amery N, Seeber C, Hamilton D, et al. (2020) Characteristics of General Movement in Infants Prenatally Exposed to Methamphetamine. J Neonatol Clin Pediatr 7: 057.

We found that male infants were more likely to have PR and have a lower gestational age of 34.3 weeks (p 0.019 table 3 ).

\begin{tabular}{|c|c|c|c|c|c|}
\hline \multirow{2}{*}{ Neonatal variables } & \multicolumn{2}{|c|}{ Normal (n=75) } & \multicolumn{2}{|c|}{ Absent fidgety $(\mathbf{n}=\mathbf{2})$} & \multirow{2}{*}{ p value $^{\mathbf{b}}$} \\
\cline { 2 - 5 } & Mean & $\mathbf{S D}^{\mathbf{a}}$ & Mean & $\mathbf{S D}^{\mathbf{a}}$ & \\
\hline Birth Weight (g) & 3084 & 489 & 2410 & 113 & $\mathbf{0 . 0 4 4}$ \\
\hline Birth Length (cm) & 48.8 & 2.9 & 48.0 & 0.0 & 0.458 \\
\hline Head circumference (cm) & 34.0 & 1.5 & 31.3 & 0.4 & $\mathbf{0 . 0 3 1}$ \\
\hline Gestational age (weeks) & 38.1 & 1.5 & 34.3 & 0.4 & $\mathbf{0 . 0 1 9}$ \\
\hline Apgar at 1 min & 8 & 1.9 & 8 & 0.0 & 0.343 \\
\hline Apgar at 10 min & 9 & 0.9 & 9 & 0.7 & 0.197 \\
\hline Motor Optimality Total Score & 26 & 3 & 12 & 2 & $\mathbf{0 . 0 1 0}$ \\
\hline Male & & - & 2 & - & \multirow{2}{*}{0.500} \\
\hline Female & & - & 0 & - & \\
\hline
\end{tabular}

Table 3: Influence of neonatal variables on fidgety movement GMs. At 4 Months.

*SD: Standard deviation

b. Asymp. Sig. (2-tailed).

\section{Griffith developmental assessment}

Developmental assessment by the Griffiths Mental Development Scales was performed on $58 \%(n=64)$ of the infants who returned at 12 months [34]. The infants ranged from 10 to 21 months old at assessment. The average age of assessment was 13 months $\left(14^{\text {th }}\right.$ month of life). The clinician performing the GMDS was blinded to the maternal drug history and GM outcomes. One infant had received a diagnosis of left hemiplegic cerebral palsy prior to assessment for this study as discussed above. The mean Griffiths General Quotient was 92.7. The strongest sub-scale for this population was Performance, with a mean quotient of 99.7. The weakest performance was in the Language sub-scale, with a mean quotient of 89.9. When comparing the GQ scores with the Optimality scores we found no significant difference between groups and the p-value of 0.720 (Table 4 and figures $1 \& 2$ ).

\begin{tabular}{|c|c|c|c|c|c|}
\hline Subscale & $\begin{array}{c}\text { All } \\
\text { meth-ex- } \\
\text { posed } \\
\text { infants } \\
\text { Median } \\
\text { quotient } \\
\mathbf{n = 6 4}\end{array}$ & $\begin{array}{c}\text { Preterm- } \\
\text { born } \\
\text { meth-ex- } \\
\text { posed } \\
\text { infants } \\
\text { Median } \\
\text { quotient } \\
\mathbf{n = 1 6}\end{array}$ & $\begin{array}{c}\text { Term-born } \\
\text { meth-ex- } \\
\text { posed } \\
\text { infants } \\
\text { Median } \\
\text { quotient } \\
\mathbf{n = 4 8}\end{array}$ & $\begin{array}{c}\text { Healthy } \\
\text { term- } \\
\text { born } \\
\text { controls } \\
\text { median } \\
\text { quotient } \\
\mathbf{n = 4 4 3}\end{array}$ & $\begin{array}{c}\text { Median differ- } \\
\text { ence between } \\
\text { meth-exposed } \\
\text { term infants } \\
\text { and healthy } \\
\text { controls (95\% } \\
\text { CI, all p-values } \\
\mathbf{< 0 . 0 0 1 )}\end{array}$ \\
\hline General Quotient & 94.0 & 87.0 & 93.5 & 113.0 & $(-22.5,-16.8)$ \\
\hline Locomotor & 91.0 & 78.5 & 95.0 & 118.5 & $(-20.5,28.8)$ \\
\hline Personal-social & 90.0 & 86.5 & 90.5 & 111.5 & $(-24.6,-16.7)$ \\
\hline $\begin{array}{c}\text { Hearing and } \\
\text { language }\end{array}$ & 90.5 & 87.5 & 91.0 & 110.0 & $(-22.2,-15.7)$ \\
\hline $\begin{array}{c}\text { Eye-hand co-ordi- } \\
\text { nation }\end{array}$ & 91.5 & 92.0 & 95.0 & 111.5 & $(-20.3,-12.9)$ \\
\hline Performance & 94.0 & 103.0 & 100.0 & 114.1 & $(-18.5,-11.2)$ \\
\hline
\end{tabular}

Table 3: Griffiths Mental Developmental Assessment subscale scores and general quotients scores for categories at 12 months compared to comparison control group [34].

\section{Discussion}

To our knowledge, we are the first Australian Drug and Alcohol Service to assess infant General Movement Assessment (GMA) to evaluate whether a detailed assessment of GMs in high- risk infants is predictive of neurological impairments in infants exposed to MA in pregnancy. There was no clear pattern of specific impairment in one area, although we identified quantitative movement differences between the writhing and poor repertoire. We found 50 infants from video observations were assessed as poor repertoire (44.6\%), which we speculated was a response to maternal methamphetamine use prior to delivery. Some infants with poor repertoire GMs had additional cramped components. This compares well to a study of infants whose mothers had major depressive disorder, who had received SSRI treatment during pregnancy, they found a lower quality of movement and more signs of central nervous system stress [18]. At the age of three to four months, more SSRI-exposed infants had monotonous movements (48\% versus $20 \%$ ) after adjusting for confounders.

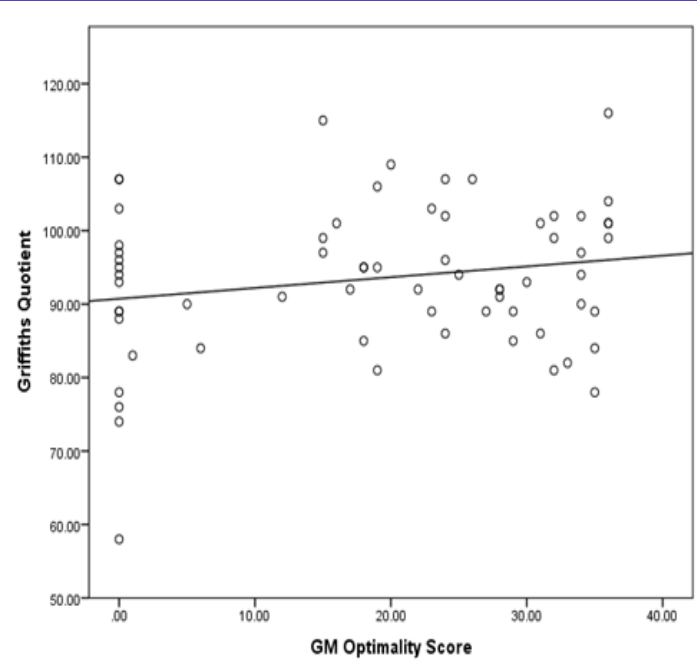

Figure 1: Griffiths vs GM Optimality Scores at 12 months.

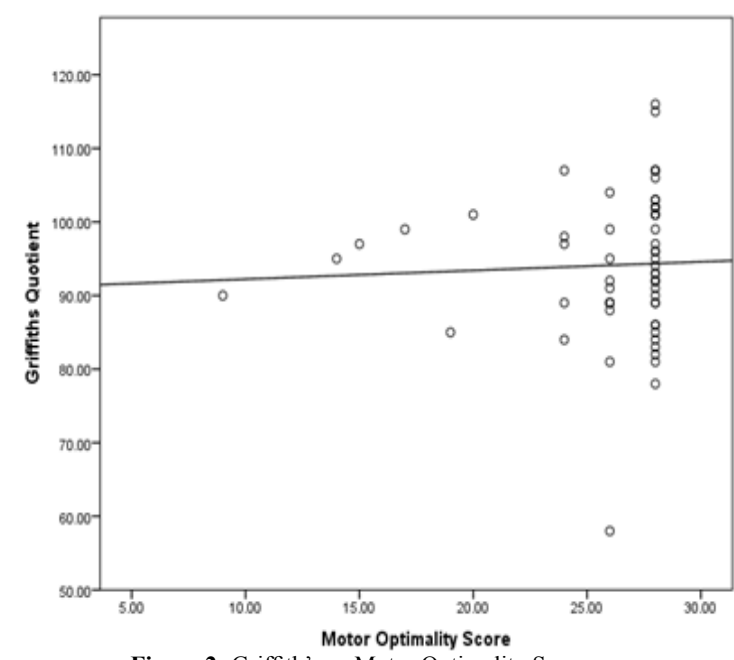

Figure 2: Griffith's vs Motor Optimality Scores.

For both regression analyses above, the relationship between optimality scores and Griffiths were non-significant.

Einspieler [19] found that Poor repertoire GMs are common among very young infants, and they can be followed by either normal, 
Citation: O'Connor A, Harris E, Amery N, Seeber C, Hamilton D, et al. (2020) Characteristics of General Movement in Infants Prenatally Exposed to Methamphetamine. J Neonatol Clin Pediatr 7: 057.

abnormal of fidgety movements suggesting their predictive value is low [35]. In contrast to this, studies have found poor repertoire GMs clearly demonstrate that the infant's nervous system is not in an optimal condition at the time of the recording $[17,21,36]$. Our results are in accordance with those of several previous studies $[19,37,38]$, showing that normal fetal movements in high-risk infants are associated with a low risk of developing CP. In line with our study, 3 studies $[17,35,39,40]$ also examined the relationship between abnormal FMs and neurological dysfunction less severe than CP. The motor optimality score did not correlate with neurological dysfunction in the general quotient at Griffiths testing at around 12 months. Cioni et al. [41], found that the results of GMs assessment were highly correlated with neurologic outcomes and there is good evidence that GMs assessment can accurately predict the development of $\mathrm{CP}$ $[17,40,42]$.

Of the 99 infants in our study that were assessed, during the firstweek post-birth and at 4 months, 2 of the infants met the criteria for motor dysfunction and were referred for further developmental support. At 4 months 77 infants returned for their video recordings, $\mathrm{n}=2$ infants had absent fidgety movements, two infants were not assessed due to poorly expressed video recordings. Seventy-Five infants had normal fidgety movements. An abnormal score of 'absent fidgety' GMs whether preceded by 'poor repertoire' or 'cramped synchronised' movements meets the essential criteria of motor dysfunction $[37,43]$ and requires further assessment and follow up.

While our study did not identify a conclusive relationship to poorer neurological outcome in infants prenatally exposed to methamphetamine perhaps due to small sample size, however, it identifies a high-risk population with risk factors at birth and at 4 months. Often there is a clinical requirement for early recognition of infants who require intervention and treatment, particularly following prenatal exposure to methamphetamine and polysubstance use making follow up essential to identify risk factors for neurological outcomes. We also found that it is very important but challenging to engage women in follow up in order to provide them or caregivers with a realistic prognosis regarding the infant's development. Women attending WANDAS do not voluntarily seek medical care due to concern of child protection, infant removal and shame about their drug use [33,44-46].

Importantly, our study demonstrated that early GMA provides information additional to perinatal risk factors in relation to MA use thus potentially helping WANDAS to further target intensive family intervention and referrals for infants who have abnormal GMs. Future work of interest could also include neuroimaging with MRI brain in infants of mothers with high MA use.

\section{Limitations}

There are a few limitations to our study we would like to point out that our follow up only included the first 12 months post-birth. Engagement and follow up was challenging and we had a poor follow up rate which may influence our results.

We had no control group as we acknowledge the difficulty in sourcing a matched control group in this population. Our final limitation was we used the maternal self-report to assess drug use. Infants born to mothers who have used MA in pregnancy may also have multiple confounding issues including poverty, nutrition, mental health and family and domestic violence, higher rates of incarceration which potentially places the infant at risk of poorer developmental outcomes.

\section{Conclusion}

The clinical significance of this detailed GMA using Prechtl's General Movements assessments lies in a better description of the global categories, which certainly has implications when used with infants with prenatal exposure to MA. Although our population did not have a higher than background rate of cerebral palsy, there was a high amount of infants with mildly abnormal general movements seen in the neonatal period (poor repertoire and hypokinesia) which could be related to maternal MA use.

\section{References}

1. Roxburgh A, Miller P, Dunn M (2013) Patterns of alcohol, tobacco and cannabis use and related harm in city, regional and remote areas of Australia. International Journal of Drug Policy 24: 488-491.

2. Bandstra ES, Morrow CE, Mansoor E, Accornero VH (2010) Prenatal drug exposure: Infant and toddler outcomes. Journal of Addictive Diseases 29: 245-258.

3. Vearrier D, Greenberg MI, Miller SN, Okaneku JT, Haggerty DA (2011) Methamphetamine: History, pathophysiology, adverse health effects, current trends, \& hazards associated with the clandestine manufacture of methamphetamine. Dis Mon 58: 38-89.

4. Smith LM, Diaz S, LaGasse LL, Wouldes T, Derauf C, et al. (2015) Developmental and behavioral consequences of prenatal methamphetamine exposure: A review of the Infant Development, Environment, and Lifestyle (IDEAL) study. Neurotoxicology and Teratology 51: 35-44.

5. Hackman DA, Farah MJ (2009) Socioeconomic status and the developing brain. Trends in Cognitive Sciences 13: 65-73.

6. Blair C, Raver CC (2016) Poverty, Stress, and Brain Development: New Directions for Prevention and Intervention. Academic Pediatrics 16: 3036.

7. Wright, Schuetter, Sauvage (2014) Methamphetamines and birth outcomes. Obstetrics \& Gynecology 1: 178-178.

8. Salom CL, Williams GM, Najman JM, Alati R (2015) Substance use and mental health disorders are linked to different forms of intimate partner violence victimisation. Drug and Alcohol Dependence 151: 121-127.

9. Coomber K, Mayshak R, Liknaitzky P, Curtis A, Walker A, et al. (2019) The role of illicit drug use in family and domestic violence in Australia. J Interpers Violence 11: 886260519843288.

10. Slamberová R, Vrajová M, Schutová B, Mertlová M, Macúchová E, et al. (2015) Prenatal methamphetamine exposure induces long-lasting alterations in memory and development of NMDA receptors in the hippocampus. Physiological Research 63: 547-558.

11. Gorman, Orme KS, Nguyen NT, Kent EJ, Caughey AB (2014) Outcomes in pregnancies complicated by methamphetamine use. Am J Obstet Gynecol 211: 4291-4297.

12. Smith BD (2008) Methamphetamine use and child welfare: Review and research agenda. Journal of Public Child Welfare 2: 511-529.

13. Stephen G, Whitworth MK, Cox S (2014) Substance misuse in pregnancy. Obstetrics, Gynaecology \& Reproductive Medicine 24: 309-314.

14. Haefele BW (2018) Acta Criminologica. CRIMSA Conference Sabinet Online. Pg no: 56-69. 
Citation: O'Connor A, Harris E, Amery N, Seeber C, Hamilton D, et al. (2020) Characteristics of General Movement in Infants Prenatally Exposed to Methamphetamine. J Neonatol Clin Pediatr 7: 057.

15. Tuhkanen H, Pajulo M, Jussila H, Ekholm E (2019) Infants born to women with substance use: Exploring early neurobehavior with the Dubowitz neurological examination. Early human development 130: 51-56.

16. Zuk L (2011) Fetal and infant spontaneous general movements as predictors of developmental disabilities. Developmental disabilities research reviews 17: 93-101.

17. Einspieler C, Marschik PB, Bos AF, Ferrari F, Cioni G, et al. (2012) Early markers for cerebral palsy: insights from the assessment of general movements. Future Neurology 7: 709-717.

18. de Vries NK, van der Veere CN, Reijneveld SA, Bos AF (2013) Early neurological outcome of young infants exposed to selective serotonin reuptake inhibitors during pregnancy: Results from the observational SMOK study. PLoS One 8: 64654.

19. Einspieler C, Prechtl HFR (2005) Prechtl's assessment of general movements: A diagnostic tool for the functional assessment of the young nervous system. Mental Retardation and Developmental Disabilities Research Reviews 11: 61-67.

20. Prechtl HF (1990) Qualitative changes of spontaneous movements in fetus and preterm infant are a marker of neurological dysfunction. Early human development 23: 151-158.

21. Einspieler C, Marschik PB, Pansy J, Scheuchenegger A, Krieber M, et al. (2016) The general movement optimality score: a detailed assessment of general movements during preterm and term age. Developmental Medicine \& Child Neurology 58: 361-368.

22. Prechtl HF (2001) General movement assessment as a method of developmental neurology: New paradigms and their consequences. The 1999 Ronnie MacKeith Lecture. Dev Med Child Neurol 43: 836-842.

23. Mutlu A, Livanelioglu A, Korkmaz A (2010) Assessment of "general movements" in high-risk infants by Prechtl analysis during early intervention period in the first year of life. The Turkish Journal of Pediatrics 52: 630-637.

24. Einspieler C, Prechtl HF (2005) Prechtl's assessment of general movements: A diagnostic tool for the functional assessment of the young nervous system. Mental retardation and developmental disabilities research reviews 11: 61-67.

25. Nakajima Y, Einspieler C, Marschik PB, Bos AF, Prechtl HFR (2005) Does a detailed assessment of poor repertoire general movements help to identify those infants who will develop normally? Early Human Development 82: $53-59$

26. Sæther R, Støen R, Vik T, Fjørtoft T, Vågen RT, et al. (2016) A change in temporal organization of fidgety movements during the fidgety movement period is common among high risk infants. European Journal of Paediatric Neurology 20: 512-517.

27. Smith LM, LaGasse LL, Derauf C, Newman E, Shah R, et al. (2011) Motor and cognitive outcomes through three years of age in children exposed to prenatal methamphetamine. Neurotoxicology and teratology 33: 176-184.

28. Einspieler C, Marschik PB, Pansy J, Scheuchenegger A, Krieber M, et al. (2016) The general movement optimality score: a detailed assessment of general movements during preterm and term age. Developmental medicine and child neurology 58: 361-368.

29. Rosenbloom L (2018) What is the role of the General Movements Assessment in clinical practice? Developmental Medicine \& Child Neurology 60: 6 .

30. Marel C, Mills KL, Kingston R, Gournay K, Deady M, et al. (2016) Guidelines on the management of co-occurring alcohol and other drug and mental health conditions in alcohol and other drug treatment settings $\left(2^{\text {nd }}\right.$ edition.) Sydney, Australia: Centre of research excellence in mental health and substance use. National Drug and Alcohol Research Centre, University of New South Wales, Comorbidity Guidelines, USA
31. Øberg GK, Campbell SK, Girolami GL, Ustad T, Jørgensen L, et al. (2012) Study protocol: An early intervention program to improve motor outcome in preterm infants: a randomized controlled trial and a qualitative study of physiotherapy performance and parental experiences. BMC pediatrics 12: 15 .

32. Harris PA, Taylor R, Thielke R, Payne J, Gonzalez N, et al. (2009) Research electronic data capture (REDCap)-A metadata-driven methodology and workflow process for providing translational research informatics support. Journal of Biomedical Informatics 42: 377-381.

33. O'Connor A, Harris E, Hamilton D, Sachmann M, Fisher C (2019) Methamphetamine use in pregnancy: Maternal and neonatal outcomes from a specialist drug and alcohol service (Western Australia). EC Gynaecology 8: 763.

34. O’Connor A, Seeber C, Harris E, Hamilton D, Sachmann M, et al. (2019) Developmental outcomes following prenatal exposure to methamphetamine: A Western Australian perspective. Journal of paediatrics and child health 56: 372-378.

35. Nakajima Y, Einspieler C, Marschik PB, Bos AF, Prechtl HF (2006) Does a detailed assessment of poor repertoire general movements help to identify those infants who will develop normally? Early human development 82: 53-59.

36. Crowle C, Walker K, Galea C, Novak I, Badawi N (2017) General movement trajectories and neurodevelopment at 3 months of age following neonatal surgery. Early Human Development 111: 42-48.

37. Adde L, Yang H, Sæther R, Jensenius AR, Ihlen E, et al. (2018) Characteristics of general movements in preterm infants assessed by computer-based video analysis. Physiotherapy Theory and Practice 34: 286-292.

38. Beccaria E, Martino M, Briatore E, Podestà B, Pomero G, et al. (2012) Poor repertoire General Movements predict some aspects of development outcome at 2 years in very preterm infants. Early Human Development 88: 393-396.

39. Bruggink JL, Einspieler C, Butcher PR, van Braeckel KN, Prechtl HF, et al. (2008) The quality of the early motor repertoire in preterm infants predicts minor neurologic dysfunction at school age. The Journal of pediatrics 153: 32-39.

40. Romeo DMM, Guzzetta A, Scoto M, Cioni M, Patusi P, et al. (2008) Early neurologic assessment in preterm-infants: Integration of traditional neurologic examination and observation of general movements. European Journal of Paediatric Neurology 12: 183-189.

41. Cioni G, Prechtl HF, Ferrari F, Paolicelli PB, Einspieler C, et al. (1997) Which better predicts later outcome in fullterm infants: quality of general movements or neurological examination? Early human development 50: 71-85.

42. Einspieler C, Prechtl HF, Bos A, Ferrari F, Cioni G (2004) Prechtl's Method on the Qualitative Assessment of General Movements in Preterm, Term and Young Infants. Mac Keith Press, London.

43. Hadders-Algra M, Groothuis AM (1999) Quality of general movements in infancy is related to neurological dysfunction, ADHD, and aggressive behaviour. Developmental medicine and child neurology 41: 381-391.

44. Stengel C (2013) The risk of being 'too honest': drug use, stigma and pregnancy. Health, Risk \& Society 16: 1-15.

45. Shahram SZ, Bottorff JL, Oelke ND, Kurtz DLM, Thomas V, et al. (2017) Mapping the social determinants of substance use for pregnant-involved young Aboriginal women. International Journal of Qualitative Studies on Health and Well-being 12: 1275155.

46. Broadhurst K, Mason C (2013) Maternal outcasts: Raising the profile of women who are vulnerable to successive, compulsory removals of their children-a plea for preventative action. Journal of Social Welfare and Family Law 35: 291-304. 


\section{If}

Advances In Industrial Biotechnology | ISSN: 2639-5665

Advances In Microbiology Research | ISSN: 2689-694X

Archives Of Surgery And Surgical Education | ISSN: 2689-3126

Archives Of Urology

Archives Of Zoological Studies | ISSN: 2640-7779

Current Trends Medical And Biological Engineering

International Journal Of Case Reports And Therapeutic Studies | ISSN: 2689-310X

Journal Of Addiction \& Addictive Disorders | ISSN: 2578-7276

Journal Of Agronomy \& Agricultural Science | ISSN: 2689-8292

Journal Of AIDS Clinical Research \& STDs | ISSN: 2572-7370

Journal Of Alcoholism Drug Abuse \& Substance Dependence | ISSN: 2572-9594

Journal Of Allergy Disorders \& Therapy | ISSN: 2470-749X

Journal Of Alternative Complementary \& Integrative Medicine | ISSN: 2470-7562

Journal Of Alzheimers \& Neurodegenerative Diseases | ISSN: 2572-9608

Journal Of Anesthesia \& Clinical Care | ISSN: 2378-8879

Journal Of Angiology \& Vascular Surgery | ISSN: 2572-7397

Journal Of Animal Research \& Veterinary Science | ISSN: 2639-3751

Journal Of Aquaculture \& Fisheries | ISSN: 2576-5523

Journal Of Atmospheric \& Earth Sciences | ISSN: 2689-8780

Journal Of Biotech Research \& Biochemistry

Journal Of Brain \& Neuroscience Research

Journal Of Cancer Biology \& Treatment | ISSN: 2470-7546

Journal Of Cardiology Study \& Research | ISSN: 2640-768X

Journal Of Cell Biology \& Cell Metabolism | ISSN: 2381-1943

Journal Of Clinical Dermatology \& Therapy | ISSN: 2378-8771

Journal Of Clinical Immunology \& Immunotherapy | ISSN: 2378-8844

Journal Of Clinical Studies \& Medical Case Reports | ISSN: 2378-8801

Journal Of Community Medicine \& Public Health Care | ISSN: 2381-1978

Journal Of Cytology \& Tissue Biology | ISSN: 2378-9107

Journal Of Dairy Research \& Technology | ISSN: 2688-9315

Journal Of Dentistry Oral Health \& Cosmesis | ISSN: 2473-6783

Journal Of Diabetes \& Metabolic Disorders | ISSN: 2381-201X

Journal Of Emergency Medicine Trauma \& Surgical Care | ISSN: 2378-8798

Journal Of Environmental Science Current Research | ISSN: 2643-5020

Journal Of Food Science \& Nutrition | ISSN: 2470-1076

Journal Of Forensic Legal \& Investigative Sciences | ISSN: 2473-733X

Journal Of Gastroenterology \& Hepatology Research | ISSN: 2574-2566
Journal Of Genetics \& Genomic Sciences | ISSN: 2574-2485

Journal Of Gerontology \& Geriatric Medicine | ISSN: 2381-8662

Journal Of Hematology Blood Transfusion \& Disorders | ISSN: 2572-2999

Journal Of Hospice \& Palliative Medical Care

Journal Of Human Endocrinology | ISSN: 2572-9640

Journal Of Infectious \& Non Infectious Diseases | ISSN: 2381-8654

Journal Of Internal Medicine \& Primary Healthcare | ISSN: 2574-2493

Journal Of Light \& Laser Current Trends

Journal Of Medicine Study \& Research | ISSN: 2639-5657

Journal Of Modern Chemical Sciences

Journal Of Nanotechnology Nanomedicine \& Nanobiotechnology | ISSN: 2381-2044

Journal Of Neonatology \& Clinical Pediatrics | ISSN: 2378-878X

Journal Of Nephrology \& Renal Therapy | ISSN: 2473-7313

Journal Of Non Invasive Vascular Investigation | ISSN: 2572-7400

Journal Of Nuclear Medicine Radiology \& Radiation Therapy | ISSN: 2572-7419

Journal Of Obesity \& Weight Loss | ISSN: 2473-7372

Journal Of Ophthalmology \& Clinical Research | ISSN: 2378-8887

Journal Of Orthopedic Research \& Physiotherapy | ISSN: 2381-2052

Journal Of Otolaryngology Head \& Neck Surgery | ISSN: 2573-010X

Journal Of Pathology Clinical \& Medical Research

Journal Of Pharmacology Pharmaceutics \& Pharmacovigilance | ISSN: 2639-5649

Journal Of Physical Medicine Rehabilitation \& Disabilities | ISSN: 2381-8670

Journal Of Plant Science Current Research | ISSN: 2639-3743

Journal Of Practical \& Professional Nursing | ISSN: 2639-5681

Journal Of Protein Research \& Bioinformatics

Journal Of Psychiatry Depression \& Anxiety | ISSN: 2573-0150

Journal Of Pulmonary Medicine \& Respiratory Research | ISSN: 2573-0177

Journal Of Reproductive Medicine Gynaecology \& Obstetrics | ISSN: 2574-2574

Journal Of Stem Cells Research Development \& Therapy | ISSN: 2381-2060

Journal Of Surgery Current Trends \& Innovations | ISSN: 2578-7284

Journal Of Toxicology Current Research | ISSN: 2639-3735

Journal Of Translational Science And Research

Journal Of Vaccines Research \& Vaccination | ISSN: 2573-0193

Journal Of Virology \& Antivirals

Sports Medicine And Injury Care Journal | ISSN: 2689-8829

Trends In Anatomy \& Physiology | ISSN: 2640-7752

Submit Your Manuscript: https://www.heraldopenaccess.us/submit-manuscript 